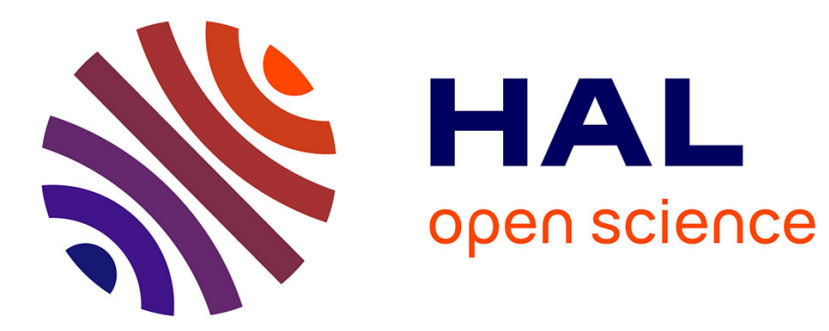

\title{
The Speeches of Theban Ambassadors in Greek Literature (404-362 B.C.) \\ Paolo A. Tuci
}

\section{To cite this version:}

Paolo A. Tuci. The Speeches of Theban Ambassadors in Greek Literature (404-362 B.C.). KTÈMA Civilisations de l'Orient, de la Grèce et de Rome antiques, 2019, La rhétorique de la diplomatie en Grèce ancienne, 44, pp.33-52. halshs-02444366

\section{HAL Id: halshs-02444366 https://shs.hal.science/halshs-02444366}

Submitted on 17 Jan 2020

HAL is a multi-disciplinary open access archive for the deposit and dissemination of scientific research documents, whether they are published or not. The documents may come from teaching and research institutions in France or abroad, or from public or private research centers.
L'archive ouverte pluridisciplinaire HAL, est destinée au dépôt et à la diffusion de documents scientifiques de niveau recherche, publiés ou non, émanant des établissements d'enseignement et de recherche français ou étrangers, des laboratoires publics ou privés. 

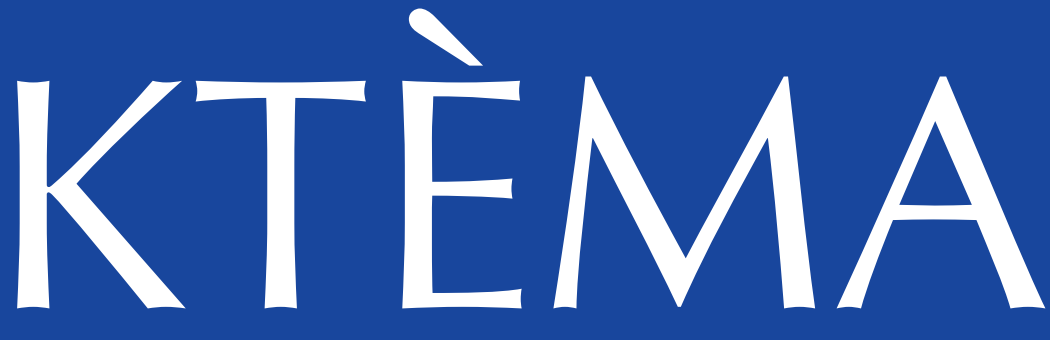

\section{CIVILISATIONS DE L'ORIENT, DE LA GRÈCE ET DE ROME ANTIQUES}

\section{La rhétorique de la diplomatie en Grèce ancienne}

Cinzia BeARzot, Laura Loddo

Laura LoDDo

Cinzia BeArzot

Paolo A. Tuci

Francesca Gazzano

Nicholas D. Cross

Davide Amendola

Jonathan R. W. PraG

Lorenzo CAMPAGNA

Cristina SORACI

Edith Foster

Walter LAPINI

Sylvain PERROT

Gianpaolo Urso

Anne JACQuemin
Political Exiles and Their Use of Diplomacy in Classical Greece

À propos du parallélisme entre deux discours d'ambassade à Sparte (Xén. Hell. V, 2, 12-19 et VI, 1, 4-16). 23

The Speeches of Theban Ambassadors in Greek Literature (404-362 B.C.)................ 33

Greek Ambassadors and the Rhetoric of Supplication. Some Notes ............................ 53

The (Im)balance of Power. Demosthenes' Complex Case

for an Alliance with the Megalopolitans.....

Presbeutikoi and Enteuktikoi Logoi in Hellenistic Interstate Relations.

Some Further Thoughts from an Epigraphical Perspective (c. 306-205 B.C.). 87

\section{Sicile hellénistique et romaine}

I.Sicily, Open Scholarship, and the Epigraphic Landscape of Hellenistic/Roman Sicily.

Trasformazioni urbanistiche in Sicilia alle origini della Provincia.

Riflessioni sul ruolo di Roma.....

Cultes et politique dans la Sicile du i ${ }^{\text {er }}$ siècle av. J.-C.

Le cas de la Vénus Érycine et de la Cérès d'Henna

\section{Varia}

Athens' Political Failures in the Central Chapters of Book 4 of Thucydides 163

Note interpretative e testuali alla col. XXII del Papiro di Derveni

La place de la musique dans la politique culturelle de Téos

dans la première moitié du $\mathrm{II}^{\mathrm{e}}$ siècle avant notre ère

Catilina legatus. Considerazioni su un discusso frammento sallustiano.

La dédicace aux Muses d'Eurydice fille de Sirrhas

(Plutarque, Sur l'éducation des enfants, 20) 


\title{
The Speeches of Theban Ambassadors in Greek Literature
}

\author{
(404-362 B.C.)
}

RÉsumé-. Cet article analyse les versions littéraires des discours prononcés par les ambassadeurs de Thèbes entre 404 et 362 av. J.-C. L'introduction, qui vise à fournir une liste de ces discours, porte sur les principaux problèmes de méthode. Puis, on propose une analyse des différents sujets et des stratégies employées par les ambassadeurs de Thèbes; on présente ensuite les données concernant la rhétorique des seuls ambassadeurs de Thèbes dont le nom est connu (Pélopidas et Épaminondas). Le dernier paragraphe propose les remarques finales. L'analyse des techniques de persuasion adoptées par les émissaires thébains explique que l'ambassadeur de Thèbes n'était pas seulement un grand orateur mais aussi un historien qualifié et un homme politique très habile.

Mots-CLÉs-. discours des ambassadeurs, rhétorique, diplomatie thébaine, Pélopidas, Épaminondas

Aвstract-. The paper examines the preserved literary versions of the speeches delivered by Theban ambassadors between 404 and 362 B.C. The introduction, after providing a list of these speeches, focuses mainly on methodological problems; then an analysis of different kind of arguments and strategies used by Theban ambassadors follows; afterwards the paper provides a survey of the evidence about the oratory of the only two Theban ambassadors whose name is known (Pelopidas and Epaminondas); the last paragraph offers concluding remarks. The analysis of persuasion techniques adopted by Theban envoys suggests that a valid Theban ambassador had to be not only an eloquent speaker, but also a skilled historian and a clever politician. Keywords-. ambassadorial speeches, Theban diplomacy, Pelopidas, Epaminondas

This paper aims at investigating the speeches of Theban ambassadors in the historical periods of Spartan and Theban hegemony in Greece, i.e. from 404 to 362 B.C. Obviously the actual speeches pronounced by them are not preserved, but sources provide their literary versions. The issue of logoi presbeutikoi has been recently studied, although they do not have a specific status in classical Greece. ${ }^{1}$ But, as Rubinstein suggests, ${ }^{2}$ it could be attractive to apply to this category of speeches what Aristotle states in a passage of his Rhetoric: in 1408a25-30, he affirms that there are many different styles $(\gamma \dot{\varepsilon} v \eta)$ in speaking, depending on the age of the speaker, if he is a child, an adult, or an elder, on the gender, male or female, but also on the provenience, being e.g. Laconian or Thessalian. Obviously here Aristotle refers also to differences related to the speaking skills, to the

(1) See e.g. Piccirilli 2002, p. 63ff., Pepe 2013, p. 16-17, 329-335 and Rubinstein 2016, p. 79-128 (see esp. p. $92 \mathrm{ff}$. for the issue of the status of logos presbeutikos in antiquity; Rubinstein observes that until the Hellenistic period envoys' speeches were not recognised as a separate and important rhetorical genre).

(2) Rubinstein 2016, p. 81. 
accent and dialectal characteristics, which in the present essay are not relevant. But, as Rubinstein remarks in his paper about diplomatic speeches, the last opposition in Aristotle's passage "strongly indicates" that oratorical conventions may differ significantly among Greek communities. Therefore, the central question is: can we identify peculiar traits of Theban diplomatic speeches in the framework of the rhetoric of diplomacy? Did Theban ambassadors have a peculiar style in speaking or did they give preference to particular kinds of argumentation in their speeches? Can we trace differences between Theban diplomatic speeches in the period before the battle of Leuctra and those belonging to the period of Theban hegemony? This being the focus, it follows that this paper faces only marginally the issue of how Theban diplomatic speeches affected Greek international politics or whether they actually were persuasive and successful. In other words, this is not a study concerning Theban diplomacy or international relationships in the first half of the fourth century B.C. ${ }^{3}$; it is rather an essay dealing with rhetorical strategies of Theban ambassadors and with the arguments more commonly used by them.

Given the above, a study regarding the rhetoric of Theban diplomacy in the forty years between the end of the Peloponnesian War and the end of Theban hegemony raises three kinds of problems beforehand ${ }^{4}: 1$ ) about the enquiry itself, namely which sources should be read; 2) about the definition of "speech", in its various forms; and finally 3) about the issue of reliability of speeches preserved by ancient sources. At the end of this introduction further brief remarks will be suggested, about 4) the terminology used in defining embassies and 5) the typology of meeting to which the ambassadors are sent.

1) The studies of a couple of scholars' at first sight could provide some information about sources concerning the topic under discussion, but they are actually far from being exhaustive: Mosley's study, the only one focusing on Theban diplomacy, because it concerns exclusively the facts of 371, and Buckler's survey about speeches in Theban hegemony, because it considers only Xenophon and, what is more important, it does not cover the period before the battle of Leuctra. ${ }^{5}$ However an extensive reading of sources is compulsory, starting of course from Xenophon's Hellenica. But also other ancient works have to be scrutinized: both historical works, such as Hellenica Oxyrhynchia (although it preserves no direct speeches) and Diodorus' Bibliotheca; and, of course, biographies written by Cornelius Nepos and Plutarch, mainly about Theban leaders (Pelopidas and in Nepos also Epaminondas), but also about other important men of the period (such as Lysander and Agesilaus). ${ }^{6}$

(3) About Theban diplomacy between 404 and 362 B.C. see e.g. the classic works of SEIBERT 1979, p. 99-133 and of AdCock-Mosley 1975, p. 64-87.

(4) For recent studies about Boeotia in the fourth century, see: MAcKIL 2013, p. 71-82 (from Leuctra to Mantinea; see also p. 58-71 for the period from 404 to 371); MACKIL 2014, p. 54-59; and the papers collected in GARTLAND 2016a and in SCHACHTER 2016a.

(5) Mosley 1972, p. 312-318; BUCKLER 1982, p. 180-204.

(6) Inscriptions do not seem to provide useful information and however an epigraphical enquiry neither is easy to be conducted, nor can provide safe guarantees about the accuracy or completeness of its results. In fact, on the on side, we have no significant keywords to look for and, on the other, given that this paper concerns embassies, not only Boeotian inscriptions should be scrutinized. However, no references to speeches of Boeotian ambassadors for the period 404-362 B.C. can be found in collections like Fossey 1991, Fossey 2014 or Papazarkadas 2014. Moreover, Rubinstein 2016, p. 92 (although mainly concerning with team embassies) states that inscriptions offer no information on the argumentation presented by the ambassadors in their speeches. Also the (so far) broadest and most important Italian study about ambassadors' speeches (PICCIRILli 2002, p. 63-118) provides an enquiry almost exclusively conducted on literary sources; the same also for PEPE 2013, p. 16-17, 329-335. For all these reasons, the present paper will be focused only on literary sources. 
2) This extensive reading of ancient sources provides results of different types: not only proper speeches, direct or indirect, long or short (which can also be part of dialogues), but generic references too. This framework can be synthesized in the following table.

\begin{tabular}{|c|c|c|c|c|c|}
\hline \multirow[b]{2}{*}{ N. } & \multirow[b]{2}{*}{ Occasion } & \multirow{2}{*}{$\begin{array}{c}\text { Source } \\
\text { and speech terminology }\end{array}$} & \multicolumn{3}{|c|}{ Typology } \\
\hline & & & $\begin{array}{l}\text { Direct } \\
\text { speech }\end{array}$ & $\begin{array}{l}\text { Indirect } \\
\text { speech }\end{array}$ & $\begin{array}{l}\text { Generic } \\
\text { reference }\end{array}$ \\
\hline 1 & $\begin{array}{l}\text { Peace negotiations at the } \\
\text { end of the Peloponnesian } \\
\text { war }\end{array}$ & 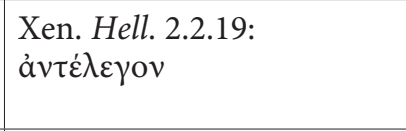 & & $\begin{array}{c}\mathrm{X} \\
\text { (short) }\end{array}$ & \\
\hline 2 & $\begin{array}{l}\text { Alliance between Thebes- } \\
\text { Athens at the beginning of } \\
\text { the Corinthian War }\end{array}$ & 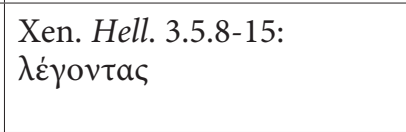 & $\begin{array}{c}\mathrm{X} \\
\text { (long) }\end{array}$ & & \\
\hline 3 & Peace congress in Sardis & 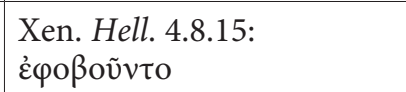 & & & $\mathrm{X}$ \\
\hline 4 & During Corinthian War & 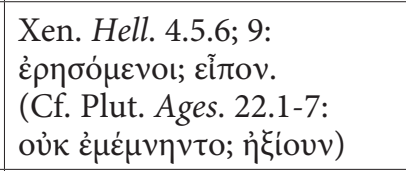 & & $\begin{array}{c}\mathrm{X} \\
\text { (short) }\end{array}$ & \\
\hline 5 & Peace congress in Susa & $\begin{array}{l}\text { Xen. Hell. 5.1.32-33: } \\
\text { ع́रejov }\end{array}$ & & $\begin{array}{c}\mathrm{X} \\
\text { (short) }\end{array}$ & \\
\hline 6 & Liberation of the Cadmea & 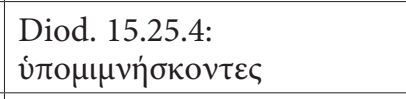 & & & $\mathrm{X}$ \\
\hline 7 & Another peace congress & 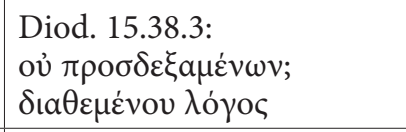 & & & $\mathrm{X}$ \\
\hline 8 & $\begin{array}{l}\text { Peace congress in Sparta } \\
\text { before the battle of Leuctra }\end{array}$ & 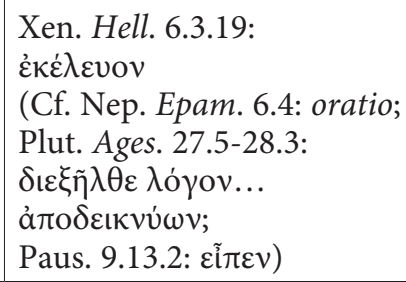 & & & $\mathrm{X}$ \\
\hline 9 & $\begin{array}{l}\text { Theban embassy to Athens } \\
\text { after the battle of Leuctra }\end{array}$ & 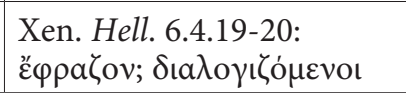 & & $\begin{array}{c}\mathrm{X} \\
\text { (short) }\end{array}$ & \\
\hline 10 & Peace congress in Delphi & 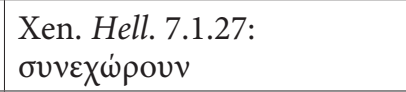 & & & $\mathrm{X}$ \\
\hline 11 & Peace congress in Susa & 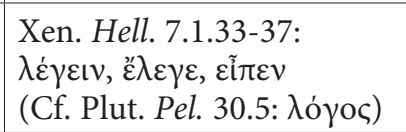 & & $\begin{array}{c}\mathrm{X} \\
\text { (short) }\end{array}$ & \\
\hline 12 & Assembly in Arcadia & $\begin{array}{l}\text { Nep. Epam. 6.1-3: } \\
\text { dixit }\end{array}$ & & $\begin{array}{c}\mathrm{X} \\
\text { (short) }\end{array}$ & \\
\hline
\end{tabular}

This survey shows primarily two important factors: that the majority of the cases falls before the battle of Leuctra (nr. 1-8), while only a few belong to the period of the Theban hegemony (nr. 9-12); and that only one direct speech is preserved, the speech of the Theban ambassador sent to Athens in 
order to ask for an alliance at the time of the beginning of Corinthian war (nr. 2). As for the other results (nr. 1 and 3-12), it has to be assessed precisely whether each of them can be considered an indirect speech or not. By using the strict criterion of the presence of a verbum dicendi, only the six cases listed in the second column could be taken in consideration. ${ }^{7}$ Therefore, the five cases of the last column need a closer investigation: the cases nr. 3 and 10 can be dismissed, because they simply mention the political view of Theban ambassadors, without anything more; the same for the case nr. 7, which moreover is historically disputed, ${ }^{8}$ but which is also interesting, because it contains a judgment about Epaminondas' oratory; conversely, the cases nr. 6 and (thanks to the versions of Plutarch and Pausanias) 8 may be cautiously considered in the present analysis because they bear a record of what the ambassadors said.

3) The actual study of Theban diplomatic speeches cannot begin before facing the issue of reliability of the speeches preserved by ancient sources, since we do not preserve any original documents of them. As it is obvious from the table above, the issue refers primarily to Xenophon's Hellenica, since it is the main source. The speeches in the Hellenica have been widely investigated, both singularly and collectively, in several respects: under their political significance, but, in particular in recent years, mostly about their supposed rhetoric nature, their moral significance, their intertextuality and relationships with speeches reported by Xenophon's predecessors. ${ }^{9}$ Surprisingly the specific problem of their historical reliability raised less interest among scholars. ${ }^{10}$ According to a wide and, although not recent, yet fundamental study of Marta Sordi, ${ }^{11}$ Xenophon in his Hellenica wrote speeches in Thucydidean manner: for this reason, she considers them usually reliable in their gist. Usher, ${ }^{12}$ taking into account only Critias' and Theramenes' speeches in Hell. 2.3.24-49, concludes that Xenophon had a written copy of the former and heard an account of the latter from an eyewitness: in both cases he was well-informed. Buckler, ${ }^{13}$ studying Xenophon's speeches of the period 371-362, on the one side states that historian's attitude towards speeches is inconsistent and that they do not preserve the actual words of the speakers and may include omissions, but on the other side he acknowledges that Xenophon had ample opportunity to learn the gist of what had been said and admits that the historian usually tried to convey the essence of the actual speech. Gray ${ }^{14}$ on the one side remarks that speeches in Hellenica have the purpose of showing moral values of the speaker and, thus, that they have more in common with Herodotus than Thucydides; besides, she adds, some common features which can be found in the speeches raise doubts about their reliability. But, on the other side, Gray admits that Xenophon could have heard some of the speeches he reports and found informants for others; besides, she argues, the fact that the views expressed in the speeches are those of the historian himself does not imply that speeches' gist is not reliable. In conclusion, these studies, although with some even substantial differences,

(7) For a survey of verbs used in diplomatic filed specifically by Xenophon, see Orsi 2002, p. 69-109.

(8) Jehne 1994, p. 59-60; Stylianou 1988, p. 320-328.

(9) In addition to the below references: DorJan-Fairchild 1975; Dalfen 1976; Higgins 1977, p. 9-10, 123-124; GraY 1981; Gray 1987; Riedinger 1991, p. 86-95; Tuplin 1993, p. 62-63, 101-114, 117-118; Dillery 1995, p. 242-249; BeARzOT 2004, p. 21-30, 45-72, 85-92; Pownall 2004, p. 97-99; Rood 2004; Marincola 2010 (Marincola 2007 does not deal with Xenophon); Baragwanath 2012; Rood 2012; Schepens 2012, p. 228-231; Pontier 2013; Tamiolaki 2014; Winter 2016; BARAGWANATH 2017.

(10) Soulis 1972, p. 120-185 (but I do not agree with his conclusions). Minor remarks in Badian 2004, p. 46 (who observes that speeches in the two first books of Hellenica are composed in a Thucydidean manner) and PonTIER 2013, p. 165 (who considers the issue of speeches' reliability).

(11) Sordi 1951, p. 345-347 (cf. Sordi 1950, p. 15-19 about direct and indirect speeches and dialogues).

(12) USHER 1968, p. 128-135.

(13) BUCKLER 1982, p. 180-204.

(14) Gray 1989, p. 137-140 (and n. 1 p. 204). 
generally do not exclude that Xenophon in his speeches could have reported the substance of what the speaker actually said and sometimes they rather argue that this is likely.

A few further remarks can be added. Firstly, it has to be pointed out that the problem of historical reliability is important within the present inquiry, but actually not essential, because it concerns primarily direct speeches (of which we have only the case nr. 2) and only far less the indirect speeches which in addition are often extremely short. As regards indirect speeches, it seems unlikely that Xenophon deliberately forged the substance also of them, not only because it could generate inconsistencies within the narrative structure of his work, but mainly because at his times a lot of people who had directly heard those speeches were still alive. Therefore, this implies that, at least in the five cases of sure indirect speeches from the Hellenica (nr. 1, 4, 5, 9, 11), there is little room for doubt about their substantial reliability. Concerning mere references to speeches or even only to political ideas of ambassadors, the cases nr. 3 and 10, as stated above, should be left aside, because they do not provide proper speeches, while nr. 8 could be considered as an indirect speech, thanks to Plutarch and Pausanias.

The cases preserved only by sources other than Xenophon $(\mathrm{nr} .6,7,12)$ have to be treated with caution, not only because in two cases it lacks a verbum dicendi, but also because Diodorus and Nepos wrote their works three centuries after the facts they narrate.

Anyway, as it has been recently pointed out by a couple of scholars, nothing prevents from studying the arguments used by ambassadors: in fact, according to Piccirilli, in diplomatic speeches reported by sources it is possible to identify the actual principles on which ambassadors' argumentation were based ${ }^{15}$; and Rubinstein states that, although it is difficult to ascertain how far we can be confident with historical reliability of speeches, nonetheless it may be possible to identify themes and argumentative strategies that were characteristic of ambassadors' speeches. ${ }^{16}$

4) Concerning the terminology used in defining ambassadors, in the cases in which Xenophon is the primary source, sometimes there are no specific terms (nr. 1, 11), while usually the ambassadors are called $\pi \rho \varepsilon \dot{\sigma} \sigma \beta \varepsilon$ c mostly $\tau \tilde{\omega} \nu \Theta \eta \beta$ ai $\omega \nu$ (nr. 2, 5, 8), only once (on the occasion of the defeat of the Spartans at Lechaion in 390) $\tau \tilde{\omega} v$ Boto $\tau \tilde{\omega} v$ (nr. 4); the Theban who, after the battle of Leuctra,

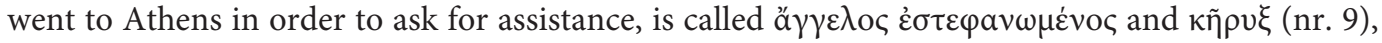
but he is not only a simple herald, because he has not only the task to announce the victory in the battle, but also to call for $\beta o \eta \dot{\theta} \theta \varepsilon{ }^{17}{ }^{17}$ As for the cases in which Xenophon is not the primary source, in Nepos a specific terminology is lacking (nr. 12).

5) Concerning the typology of meeting to which the ambassadors are sent, three cases out of eight deal with bilateral negotiations (nr. 2, 9 with the Athenians; nr. 4, with the Spartans), while there are more than two parts in the other five cases: in the occasion of the peace at the end of the Peloponnesian war (nr. 1), of the negotiations in Arcadia in the presence also of the Athenians (nr. 12) and, above all, of the meetings for common peace in Susa both in 387/6 and in 367 (nr. 5, 11) and in Sparta before Leuctra (nr. 8).

Given these introductory remarks, an investigation about Theban diplomatic oratory can be now carried out: the paper will focus in the first place on arguments and strategies used in Theban diplomatic speeches (par. I) and then on the diplomatic oratory of Pelopidas and Epaminondas (par. II).

(15) Piccirilli 2002, p. 65-70.

(16) Rubinstein 2016, p. 92-93.

(17) The Greek terminology of ambassadors is often approximate (ADCOCK-MosLEy 1975, p. 122); for some differences between ambassadors and heralds, MosLey 1973, p. 81-92. 


\section{ARGUMENTS AND STRATEGIES IN THEBAN DiPLOMATIC SPEECHES}

Within the considered speeches, the highest concentration of the use of rhetorical strategies can be found in the discourse of the anonymous Theban envoy at Athens in 395 (nr. 2): this is far from surprising, since it is the only direct speech and moreover it is quite long. On the contrary, in three cases, the (indirect) speech is too short for reconstructing persuasion techniques adopted by the respective ambassadors (nr. 1, 5 and, only for Xenophon's version, 8). Given that the genre of ambassadorial speech has been scarcely studied as a whole, ${ }^{18} \mathrm{I}$ will hereunder provide a list of the main rhetorical strategies, beginning with those that are less attested.

1) Refuting charges. The Theban envoy at Athens in 395 begins his speech by saying that it is not fair that his fellow citizens are blamed by the Athenians for their conduct at the end of the Peloponnesian war (nr. 2, Xen. Hell. 3.5.8). ${ }^{19}$ This seems an answer to a criticism made against the Thebans, maybe also openly, during the meeting in which the Athenians were listening to the envoy's speech. But if, as it seems probable and as it appears from Xenophon, the debate followed his speech, the rhetoric strategy adopted would be particularly interesting, because the envoy would have cleverly prevented a blame which he considered that could be made against him. Besides, also the way he tried to exonerate his city from this charge is remarkable: the explanation he gave (it was not a fault of all the Thebans, but only of the single delegate within the council of Spartan allies ${ }^{20}$ ) deals with the issue of responsibility of the delegate, seems to be an excuse and may have been used by Xenophon to discredit the Thebans.

2) The goal is easy to achieve. In the same speech (nr. 2, Xen. Hell. 3.5.15), the envoy states that it would be easier to overthrow the Spartan insolence than it had been to overthrow the Athenian empire, because the Athenians ruled thanks to their navy over cities devoid of a navy, while the Spartans, who were few in number, claimed to rule men who were numerous and well-armed. This kind of argument, which is a commonplace in political oratory, ${ }^{21}$ aims to persuade the Athenians to take action against the Spartans. It could be significant that, in Xenophon's version of the speech, it is placed at the very end of it, being considered as a decisive argument for persuading the Athenians to join to the Thebans against Sparta. In effect, notwithstanding the doubts of Thrasybulus, "all the Athenians" voted to bring assistance to the Thebans.

3) Omitting the message. Concerning Agesilaus' operations in the area of Corinth in 390, Xenophon reports that, after significant Spartan successes, the king was reached by $\pi$ o $\lambda \lambda$ ai $\pi \rho \varepsilon \sigma \beta \varepsilon \tilde{a} \alpha$, amongst which also that of the Boeotians, in order to call for peace; but Agesilaus haughtily pretended not to receive them, even though they were accompanied by their proxenos Pharax (nr. 4, Xen. Hell. 4.5.6). ${ }^{22}$ Notwithstanding this is not a rhetoric stratagem, the brightness of

(18) Piccirilli 2002, p. 63 ff.; Pepe 2013, p. 16-17, 329-335; Rubinstein 2016, p. $79-82$ (Wooten 1973 and Magnetto 2019, p. 103-106, but only about Hellenistic period).

(19) On the well known speech of Theban envoy to Athens in 395, see e.g.: Soulis 1979, p. 143-147, 185; GraY 1989, p. 107-114 (see p. 108: according to Gray, the speech is mainly Xenophon's own fabrication); Riedinger 1991, p. 152-154, 175-176; Tuplin 1993, p. 62f.; BucK 1994, p. 37 (and n. 52 p. 139 about the reliability of the speech); Krentz 1995, p. 198200; Bearzot 2004, p. 21-30 (with previous bibliography, notably in p. 22 n. 6); Rood 2012, p. 80-85; Low 2007, p. 202 ff.; SCHEPENs 2012, p. 228-231 (see n. 54 p. 229, where he seems to agree with Gray 1989, p. 108); TAMIOLAKi 2014, p. 131-133; Occhipinti 2016, p. 188-189; Rubinstein 2016, p. 116 ff. See also below. Concerning the relations between the Thebans and the Athenians in this period, BuCKLER 2000, p. $319 \mathrm{ff}$.

(20) BeARzot 2004-2005, p. 25.

(21) See e.g. Her. 5.45.3-4 (Aristagoras of Myletus) and Thuc. 6.17.2-6 (Alcibiades).

(22) Regarding the historical background: Gray 1989, p. 157-163; RIEDINGER 1991, p. 72-79; BUCK 1994, p. 55-56; FERRARIo 2012, p. 349-351. 
the ambassadors ${ }^{23}$ is certainly worth noting: they tried to win over Agesilaus thanks to the support of a Spartan citizen. But the actual rhetoric stratagem is another: when, shortly after, a severe defeat in Lechaion was announced to Agesilaus, he summoned the Boeotian ambassadors and asked them why they had come; but this time they made no mention of the peace and said instead that they wished to join their own army (Xen. Hell. 4.5.9). ${ }^{24}$ This incident is remarkable on two respects. It shows a case in which Theban envoys (or rather Boeotians, as exceptionally Xenophon calls them here) changed their strategy: this occurred also in occasion of the oath of the peace of Antalcidas (nr. 5, Xen. Hell. 5.1.33), but in that case Theban envoys had to go back home to ask for permission about changing their position (obviously in $\mathrm{nr} .4$ it would be impossible to consult with homeland and moreover the matter was much less important; besides, also the status of the ambassadors could be different in the two $\operatorname{cases}^{25}$ ). Furthermore, in this case Theban ambassadors resorted to a particular rhetoric strategy, namely that of silence: they decided to omit what they were sent to report, because the circumstances were changed. This stratagem shows a good degree of political intelligence, because it demonstrates a quick adjustment to changed conditions.

4) Use of propagandistic slogans. ${ }^{26}$ For the peace congress held in Sparta before the battle of Leuctra (nr. 8) Xenophon (Hell. 6.3.19) and Diodorus (15.50.4) do not preserve any actual speech and they only mention that Agesilaus refused to allow the Theban ambassador to sign the peace on behalf of all the Boeotians. ${ }^{27}$ Instead, Nepos (Epam. 6.4) ${ }^{28}$ Plutarch (Ages. 27.5-28.3) ${ }^{29}$ and Pausanias $(9.13 .2)^{30}$ preserve some interesting pieces of information: from these sources emerges that in Sparta Epaminondas held a speech, whose content is known only thanks to Plutarch (who also characterises his rhetorical style ${ }^{31}$ ), and then debated with Agesilaus, as it is reported by the two biographers. With regard to rhetoric of diplomacy, the speech is noteworthy for two aspects: the analysis of the present situation, because Epaminondas claimed that the war had made Sparta great, while damaging all the other states; and the use of propagandistic slogans, both in ideas,

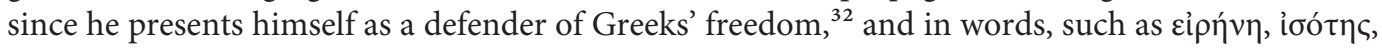

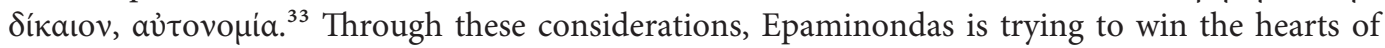
the Greek delegates who were in Sparta, by presenting himself as mindful of the rights and careful

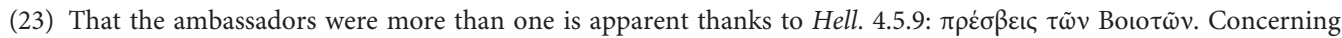
ambassadorial teams and rhetorical strategies, Rubinstein 2016, p. 88-93.

(24) See also Plut. Ages. 22.1-7 (Shipley 1997, p. 265 ff.).

(25) It is not known whether the Boeotian ambassadors mentioned in Xen. Hell. 4.5.9 were plenipotentiary or not.

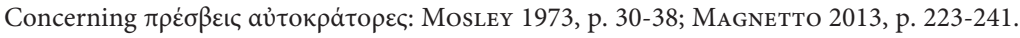

(26) I use here the notion of propaganda with the meaning defined in 1974 by Marta Sordi, who dedicated to this issue three consecutive books of her "Contributi dell'Istituto di Storia antica": propaganda is "ogni gesto, azione, manifesto, slogan, discorso, opera scritta, immagine o rappresentazione artistica che si proponga di esercitare una pressione psicologica sull'opinione pubblica per accreditare o screditare un'idea, una persona, un prodotto, una linea politica o religiosa" (SORDI 1974 , p. 5). In this section of my paper I am dealing mainly with "slogans", i.e. ideas or words used by Theban ambassadors in order to present themselves in misleading and tendentious way as defenders of principles like justice, peace and freedom.

(27) Concerning the peace of Sparta before the battle of Leuctra: Mosley 1973, p. 27; BuckLER 1980, p. 49-54; Buck 1994, p. 111-113; Jehne 1994, p. 65-74; Stilianou 1998, p. 382-386; Bearzot 2004, p. 93-107. For the Athenian ambassadors, see also: Gray 1989, p. 123-313; Riedinger 1991, p. 198-206; Tuplin 1993, p. 101-110; SChepens 2001, p. 81-96; BeArzot 2004, p. 85-92; Rood 2012, p. 85-86; Rubinstein 2016, p. 100-110. See in particular MosLey 1972, p. 312-318, which however does not deal with Epaminondas' speech in the congress.

(28) Bradley 1991, p. 92.

(29) SHIPley 1997, p. 310-315.

(30) Moggi 2010, p. 295. Concerning fourth century Boeotia in Pausanias, see mainly Gartland 2016b, p. 80-98.

(31) See par. II.

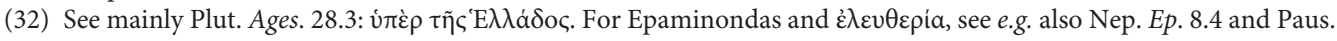
9.15.6 (and Pascual Gonzáles 2018, p. 100).

(33) SHIPLEy 1997, p. 312-313. For other forms of propaganda used by Epaminondas, SoRDi 1974, p. 45-53. 
of the prosperity of all the Greeks: this is obviously a propagandistic attitude. A similar approach may be found in the peace congress of 367 in Susa as well, when Pelopidas resorted to the slogan of avitovouia (Xen. Hell. 7.1.36). ${ }^{34}$ This shows that both the Theban leaders resorted (not only before, but also after Leuctra) to this kind of propagandistic arguments, that were common in the fourth century international political debate. ${ }^{35}$

5) Use of rhetorical questions. Epaminondas' speech was immediately followed by a debate, known thanks to Plutarch (Ages. 28.1-3; nr. 8) and Pausanias (9.13.2; nr. 8), in which Agesilaus asked him whether he felt that it was Síkaıv kaì loov that the cities of Boeotia should be independent from Thebes. In Plutarch's version, Epaminondas answered with a question, asking him provocatively, not only once but twice, whether he was willing to make the cities of Laconia independent; in the shorter version of Pausanias (who besides misplaces the episode), the same idea recurs, but only once and not in the form of question. Anyhow, this is a rhetoric strategy aiming to reverse on his interlocutor a question that was clearly provocative. Obviously it is impossible to determine whether the use of the rhetorical question is genuine or only a rhetoric dramatization created by Plutarch, but anyway the use of a provocative behaviour has to be considered believable in ambassadors' speeches; and this could be a characteristic trait of Epaminondas' "diplomatic" oratory in occasion of the Spartan congress of 371.

6) Use of mythic arguments. In a session of the Arcadians' assembly in $366,{ }^{36}$ while the Athenian envoy Callistratus advocated their alliance with Athens, the Theban ambassador, who again was Epaminondas, urged them to ally with the Thebans and the Argives, obviously in order to overthrow Spartan rule in the Peloponnese. Callistratus slandered the Thebans reminding that from Argos came the matricides Orestes and Alcmaeon and from Thebes Oedipus, who killed the father and married the mother.

According to Nepos, Epaminondas firstly "discussed the other questions" (cum de ceteris perorasset; nr. 12, Nep. Epam. 6.1-3). The source does not provide any detail about these "cetera", but it seems that Epaminondas arranged carefully his speech, placing at the end of it an argument that openly contradicted Callistratus' words. The rhetoric issue of dispositio should obviously be very important for an ambassador, although unfortunately we have scarce evidence about this in the sources. In fact, a rhetorical analysis of the arrangement of arguments could be conducted almost exclusively on the only direct speech preserved, that of the Theban envoy at Athens in 395, in which in fact the last argument was particularly effective: the Spartan empire is easy to overthrow (see above, item nr. 2).

But what is more remarkable is that, after discussing these "cetera", Epaminondas added that he was amazed at the stultitia of the Athenian ambassador, who did not understand (non animadverterit) that the men mentioned by Callistratus were born blameless in their native land, but, after they had been exiled from their country for the crimes committed, they had found asylum amongst the Athenians (nr. 12; Nep. Epam. $6.3^{37}$ ). It is worth noting that, having the Athenian envoy used a mythical argument to support his view, Epaminondas proves himself even more skilled than his colleague in the same field, because he is able to reverse the argument used by him. This rhetorical device closely resembles item number 5 above: in both cases the ambassador resorts

(34) About this event see also below, 8a and par. II.

(35) It is not my intention to discuss the whole issue of the use of propaganda in Boeotian history. For a few examples, see Sordi 1966, p. 15-24 and Bearzot 2011, p. 271-284. For the use of slogans of autonomy and freedom in diplomatic speeches, Piccirilli 2002, p. 99-101.

(36) BUCKLER 1980, p. 197-198 (n. 24 p. 313 with bibliography concerning the historicity of the event); BUCKLER 1982, p. 199; Bradley 1991, p. 92 (see p. 104, n. 11 for doubts about the authenticity of this episode); MACKIL 2013, p. 78.

(37) See also Plut. Mor. 193c-d and $810 f$. 
to the same argument used by the previous speaker (in the Spartan congress, the independence of the Peloponnese, while in the Arcadian assembly, mythical figures who murdered someone), being able to overturn them. And it is worth noting that in both cases, attested by different sources (Plutarch and Pausanias for the Spartan Congress, Nepos for the Arcadian assembly), the ambassador was Epaminondas.

However, this episode did not end well for the Thebans, given that the Arcadians established the alliance with the Athenians (Xen. Hell. 7.4.2-3). But Xenophon's account suggests that the Arcadian leader Lycomedes persuaded the assembly to make an alliance with them: therefore, Epaminondas' failure depends not much (or not only) on his failings in performing his duties as ambassador, but rather on domestic policy issue of Arcadia.

7) Use of sarcasm. Again in the same occasion of the Arcadian assembly (nr. 12), like in nr. 5, Epaminondas proves himself as scarcely "diplomatic" towards his colleague, since he not only openly contradicts his words, but also does it scathingly; but his strategy is not reckless, because his aim is not to flatter the Athenians, but to gain Arcadians' alliance.

8) References to the past, the present or the future. The most recurrent rhetoric strategy in Theban diplomatic oratory is the reference to past or present circumstances, or even to the future. These references are mainly concentrated in cases nr. 2, 6, 9 and 11 and this enables us to conclude that the appeal of this kind of argumentation is not characteristic of a specific period or ambassador, but it occurs in various occasions basically through the whole considered period, equally before and after the battle of Leuctra.

8a) References to the past. ${ }^{38}$ The long direct speech of the anonymous Theban ambassador at Athens in 395 (nr. 2; Xen. Hell. 3.5.8-15), which have been widely studied, ${ }^{39}$ is filled with references to the past, notably to the last decade of events: the reinterpretation of the Theban vote concerning the fate of Athens at the end of the Peloponnesian war (see nr. 1); the vote by which they decided not to help the Spartans in their expedition against the Piraeus; the fact that the Spartans imposed to Athens an oligarchic regime; the fact that the "men of the city", having been handed over to the demos, were saved by the demos itself. Regarding the Athenian allies, the ambassador remarks that, once the Spartans became their leaders against the Athenians, they displayed their real feelings against Athens; but later, instead of freedom, the Spartans gave them the tyranny both of the harmosts and of decarchs. And regarding the Spartan allies, he observes that during the Peloponnesian war Sparta used their assistance, while, after the peace, Sparta behaved like a tyrant against them, preferring to the allies even helots as harmosts. If, as assumed before, we consider that at least the gist of this speech has to be genuine, ${ }^{40}$ the Theban orator appears a subtle politician, able to use and even reinterpret recent history in order to support his claims. He uses historical arguments with a dual purpose: of praising the Thebans, even finding an excuse for awkward situations such as that of 404; and of discrediting the Spartans, in order to induce the Athenians to the alliance with Thebes against them. Besides, an integral component of the use of past in diplomatic speeches is the resort to the well-known argument of the merits achieved in the past: this is obvious when the ambassador reminds that the Thebans did not help the Spartans in

(38) Concerning this topic: Marincola 2010, p. 266-269 (in general); Pontier 2013, p. 174-184 (in Xenophon's speeches). The topic of the use of the past has been extensively studied in the field of oratory, recently by CanEVaro 2017, p. 171-212.

(39) See above, n. 19.

(40) Some scholars prefer to emphasise the insertion of Xenophons' ideas in the construction of this speech. See, with various observations: Perlman 1964, p. 72; Westlake 2010, p. 464, n. 15; Schepens 2012, p. 229 n. 54. 
the expedition against the Piraeus ${ }^{41}$; this is something like a "moral" argument, because it makes the audience feel obliged to return the favour.

A second case for references to the past is the embassy that the Thebans sent to Athens after the liberation of the Cadmea ${ }^{42}$ (nr. 6), which has to be considered carefully, because it is far from sure that the source preserves an indirect speech (see above). According to Diodorus (15.25.4), the unnamed ambassador asked for Athenian assistance before the Spartans could reorganize themselves and regain the citadel; he argued his claim recalling that also the Thebans provided aid in restoring Athenian democracy at the time of the Thirty Tyrants. It has been pointed out that this is not strictly correct, because the Thebans just protected the Athenian exiles, but did not join Thrasybulus' force in $404 / 3 .^{43}$ This proves that also in this occasion the past attitude of the Thebans towards Athens is usually recalled with slight alterations, in this occasion (nr. 6) in order to increase their own merits, while in 395 (nr. 2) to minimize their own responsibilities.

The latest past is recalled in the indirect speech of the Theban envoy at Athens after Leuctra (nr. 9; Xen. Hell. 6.4.19). ${ }^{44}$ Actually, this man was prevented from delivering a formal speech in the boule, because the Athenians were upset, and he was dismissed without having been officially listened to. In any case, he probably disclosed to someone the substance of his message, that Xenophon reports: he supported his request for assistance from Athenians by announcing the greatness of the Theban victory at Leuctra and by saying that finally it was the appropriate time to take revenge on the Spartans. A couple of oratory strategies are employed: an allusion to the wrongs made by the Spartans, which tickles Athenians' desire for revenge, and the use of the immediate past, namely of the recent happy event of Leuctra, which proved that the Spartans were in trouble and that it was the right time to defeat them definitively. Ultimately, the argument of the Theban envoy was the new balance of power after Leuctra, i.e. the serious Spartan defeat and the rise of the Theban hegemony; nonetheless, the Athenians, because of their hatred towards Thebes, did not want to take sides, although they were in charge of an anti-Spartan league. ${ }^{45}$

The peace negotiations at Susa in 367 are perhaps the most important showcase event for the Theban hegemony, since they involved also the Persian king Artaxerxes. ${ }^{46}$ It is remarkable that for this relevant occasion the Thebans sent Pelopidas as ambassador. ${ }^{47}$ Xenophon preserves two indirect speeches of him, held in front of the Persian king and of the delegates of the Spartans, the Arcadians, the Eleians and the Athenians (nr. 11; Xen. Hell. 7.1.33-37). In the second speech, in response to the question of the king about which terms for the peace Pelopidas wished to establish, the Theban listed the autonomy of Messenia, ${ }^{48}$ the disarming of the Athenian fleet and a declaration

(41) This argument is similar to the topic of mutual aid, on which Piccirilli 2002, p. 96-98 and Bearzot 2004-2205, p. 17-32 (25-27 for this episode).

(42) Regarding the liberation of Cadmea: BucK 1994, p. 72-80; Sordi 1995, p. 415-522; Vela TejadA 2005, p. 465-477; RZEPKA 2010, p. 115-118.

(43) Stylianou 1998, p. 237. See Xen. Hell. 2.4.2; Plut. Pel. 6.5 (with Georgiadou 1997, p. 99); Iust. 5.9.4ff.

(44) Concerning this context: Adcock-Mosley 1975, p. 82; Rubinstein 2016, p. 94.

(45) Given that the Theban envoy, who had not been received by the boule, failed in persuading the Athenians, the Thebans appealed to Jason of Pherae. But the sources do not provide any speech for this second embassy (Xen. Hell. 6.4.20ff.).

(46) Concerning this peace congress: AdCock-Mosley 1975, p. 85; BuCKLER 1980, p. 151-157; Riedinger 1991, p. 180184; Jehne 1994, p. 82-90; Georgiadou 1997, p. 205; PicCirilli 2002, p. 26, 100-101, 109; Sterling 2004, p. 456-457; Bearzot 2008-2009, p. 100-110; Schachter 2014, p. 325-326. Specifically about Pelopidas' speech in this occasion, see below par. II with further bibliography. For other sources about the congress of peace of 367: Nep. Pel. 4.3; Paus. 6.1.3; 6.3.9.

(47) According to Plut. Artax. 22.8, also Ismenias was part of the Theban embassy in this occasion: see Orsi 1987, p. 295; Binder 2008, p. 204; BEARzot 2008-2009, p. 106; see also below, par. II. However, no source attests that he delivered a speech.

(48) See also Diod. 15.81.3 (Stylianou 1998, p. 500-501) and Nep. Pel. 4.3 (Bradley 1991, p. 115). 
of war against anyone who did not accept these clauses ( $\$ 36)$. But the appeal to the past occurs in the first speech, which is much longer and lists the Theban merits towards the Persian king and among the Greeks ( $\$ 34-35)$ : Pelopidas stated that the Thebans were the only Greeks who at Plataea fought alongside the Persians; that they have never fought against the king; that the Spartans were fighting against them because they did not take part in the Spartan expedition against the king and prevented Agesilaus from making sacrifices in Aulis before leaving towards Persia ${ }^{49}$; that the Thebans had been able to sack Laconia after the battle of Leuctra (but it is not clear whether this item was part of the speech or not); and that the Argives and the Arcadians had been defeated by the Spartans when the Thebans did not support them. The aim of Pelopidas' speech is threefold: he wanted to show that the Thebans were trusted allies of the king, that they were enemies of the Spartans because of their relationship with Persians and that their power was great in Greece. Just like Epaminondas in other circumstances, Pelopidas as well does not avoid slight historian inaccuracies: for example, it is well known that the Thebans were not the only medizers among the Greeks and that the war between Sparta and Thebes is not so much due to the reasons listed by Pelopidas, as to the dissatisfaction of the former allies of Sparta after the Peloponnesian War. ${ }^{50}$ These "inaccuracies" are obviously aiming at presenting the Thebans in a favourable light and history is used for supporting their political claims. Moreover, it is remarkable that what we called here "inaccuracies", are defined as "truth" by the Athenian ambassador Timagoras, who spoke after Pelopidas confirming his words. ${ }^{51}$

The four cases considered show that references to history are not occasional in Theban diplomatic oratory. Although this is not distinctive with respect to other Greek diplomacies, ${ }^{52}$ the political use of the past is very interesting. Of course in this kind of argument the degree of probability of an intervention on the part of the historian is not low, especially in the speeches preserved by Xenophon and when they deal with the relationships between Sparta and Thebes, a subject concerning which he has never been totally neutral: admittedly this could have partly influenced his speech-making. Anyhow, also in the light of what has been remarked above in the first paragraph, the overall information that comes from the considered cases, although with some caution, seems to be considered, in my opinion, acceptable.

In three out of four cases the Thebans are addressing the Athenians, asking for their support, while in the last case the audience is much wider, because the event concerns negotiations for a common peace. The historical references range between the second Persian war and Leuctra, but they are mostly concentrated on the events subsequent to the end of Peloponnesian war. Also as a consequence of the chronological proximity of these references, it was impossible for the orators to lie openly, because otherwise their mendacity would have been easily detected and, therefore, these references would have been counterproductive; this is the reason why we rather find cases of slight historical inaccuracies, by which the orator tries to convey a particular perspective of the political framework.

8b) References to the present. Diplomatic speeches naturally include also references to contemporary political and military situation. The main example of this typology of argumentation comes from the direct speech of the Theban ambassador in 395 (nr. 2). Interpreting the ambitions of the Athenians, he stated (Xen. Hell. 3.5.10-12) that all the Greeks know that the Athenians aimed

(49) Xen. Hell. 3.4.3-4.

(50) I do not agree with Georgiadou 1997, p. 204, who claims that Pelopidas was "neutral" in his reconstruction of the past.

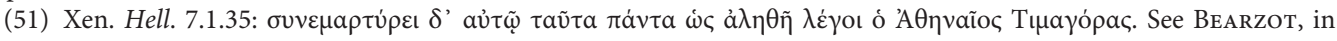
press.

(52) E.g. Thuc. $1.67 \mathrm{ff}$. 
to recover their former hegemony; besides, in order to prove that the Spartans were universally loathed, he reviewed the people of the Peloponnese, showing that the Argives, the Eleans, the Corinthians, the Arcadians, and the Achaeans had several grounds for hating the Spartans. Moreover, the ambassador remarked that the facts recalled by him prove that he said the truth ( $\dot{\alpha} \lambda \eta \theta \tilde{\eta} \lambda \dot{\varepsilon} \gamma o \mu \varepsilon v)$ : this reference to the $\dot{\alpha} \lambda \dot{\eta} \theta \varepsilon \alpha^{53}$ and also the rhetorical stratagem of "proving" a claim through some examples are quite remarkable in an ambassadorial speech.

A brief reference to the present military and political situation comes also from Plutarch's version of the speech of Epaminondas in Sparta before Leuctra, when he stated that the war made Sparta great, while all the other states were suffering, and therefore peace was strongly needed (nr. 8; Plut. Ages. 27.4). ${ }^{54}$

References to the present provide a picture that is similar to what had been already noted for references to the past: they are both made in order to support the ambassador's claims and they are both not necessarily completely correct. For example, Epaminondas' allegation concerning the fact that Sparta was becoming stronger thanks to the war seems tendentious: in fact, in the five years before the Spartan peace congress of 371, Spartans had been defeated at Naxos and Alyzia by the Athenians and at Tegyra by the Thebans, who conversely were strengthening their koinon recently reconstructed. This proves that also the references to the present situations may be "adjusted" in order to better persuade the audience.

8c) References to the future. At least in one case, the ambassador makes allusions to the future. In the direct speech of the anonymous Theban in Athens in 395 (nr. 2) some examples can be found: he states that the Athenians will recover their empire by supporting those who are oppressed by the Spartans (Xen. Hell. 3.5.10 and $14^{55}$ ) and that the Thebans will fight with them more stoutly than when in the past they supported the Lacedaemonians $(\$ 14)$. The ambassador is making in the former case a prediction, aimed to teasing Athenians' ambitions of power, while in the latter a promise, that ensures the firm support from the Thebans: by means of both allusions, he is supporting his own proposal, using a rhetoric strategy which efficiency lies in the fact that there were no sure means to contradict his words.

\section{THE DIPLOMATIC ORATORY OF PELOPIDAS AND EPAMINONDAS}

In the cases studied in present survey, the only Theban ambassadors who delivered speeches are Pelopidas and Epaminondas ${ }^{56}$ : consequently, it could be interesting to examine more closely their characteristics as diplomatic orators. Main sources are Diodorus, Nepos and Plutarch, while Xenophon, given his usual coldness towards the Thebans, preserves only one piece of information;

(53) See Bearzot, in press.

(54) Other occasions are less interesting in the present study, devoted to the oratory of diplomacy, but are still remarkable because, although we do not find an analysis of the contemporary situation in the actual speech, nevertheless the ambassadors take advantage of a position of superiority and, in the light of that, shape their political claims: this is particularly evident in occasion of the Theban legation to Agesilaus in 390, when, after the announcement of Spartans' severe defeat in Lechaion, the ambassadors decided not to ask any more for peace (nr. 4) and in occasion of the peace congress in Susa in 367, when Pelopidas took advantage of the Theban hegemony and of the support of the Persian king (nr. 11).

(55) KRENTZ 1995, p. 199-200 correctly remarks that the same idea is expressed with different words in $\$ 10$ and $\$ 14$ : this depends on the different perspectives of the two claims.

(56) More generally, it could be stated that for the considered period all the Theban ambassadors are unnamed, apart from Pelopidas, Epaminondas and probably also Ismenias (but no source attests any speech delivered by him; see n. 47, 62, 70). We have much more information about the composition of Spartan and Athenian embassies: MosLEy 1973, p. 50-62. 
the first three authors supplies not only mentions of speeches or indirect speeches, but also remarks about the rhetorical style of the two ambassadors.

The information regarding Pelopidas' diplomatic oratory concerns only the case of the peace negotiations in Susa in 367 (nr. 11). ${ }^{57}$ As noted above, for this occasion Xenophon preserves two indirect speeches in which the ambassador made wide use of the appeal to the past and presented specific conditions for the peace: Pelopidas appears as self-confident and straight to the point. Although, as it is known, the peace treaty was not ratified, this occurred not because of Pelopidas' inadequacy in the Susa conference, but to the refusal later opposed by Corinth and other cities (Xen. Hell. 7.1.40).

Plutarch's information about Pelopidas' oratory is abundant but not completely consistent. On the one side, the author praises the Theban orator: according to Pel. 30.5, Artaxerses stated

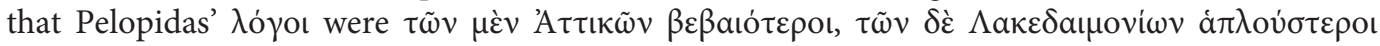
(steadier than those of the Athenians and more straightforward than those of the Lacedaemonians). Through these remarks, the Persian King praises the solidity and the simplicity of Pelopidas' words, in comparison with those of the Athenians and of the Spartans. In fact, further ahead Plutarch adds that Artaxerxes, although he had appreciated more Antalcidas, sent to Pelopidas greatest and most splendid gifts and, above all, granted him his demands (Plut. Pel. 30.7). Moreover, Plutarch elsewhere provides a list of aphorisms attributed to him (Mor. 194c-e), that, although they do not concern his diplomatic activity, could testify (if authentic) his ability in this field. But, on the other side, the biographer slightly reduces the relevance of Pelopidas' speeches in Susa, since he states that his reputation was greater for the arms than for his actual rhetorical skills (Pel. 30.13); moreover, Plutarch reports that, in an unspecified embassy, Pelopidas, realising that he was not a good speaker

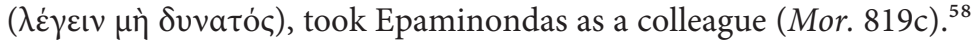

Thus, information about Pelopidas' oratory, completely coming from Plutarch, seems at least partially inconsistent. Georgiadou observes that Plut. Pel. 30.5 does not imply any oratorical ability of Pelopidas, since his "inadequacy" in this area is elsewhere attested (Pel. 30.13; Mor. 819c), and

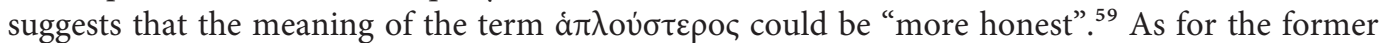
aspect, oratory admittedly was not the main talent of Pelopidas, but I prefer to avoid the idea of "inadequacy", which seems to me too trenchant. As for the latter aspect, I am not sure that Plutarch was referring to "honesty" and I rather prefer to intend that the biographer was characterizing Pelopidas' diplomatic oratory as straight to the point, plain and direct. This is consistent with the little that we know about the oratory of the Theban general; unfortunately, his particular style in diplomatic oratory, if there was any, is impossible to trace confidently, because further evidence lacks.

In my opinion, it seems unlikely that Pelopidas was completely $\lambda \dot{\varepsilon} \gamma \varepsilon \imath \nu \mu \eta ̀ ~ \delta v v a \tau o ́ c$, otherwise he would not have been chosen for an important embassy such that at Susa. But, at the same time, we must not forget that, according to the sources, Pelopidas was renowned for his skill with the arms, while Epaminondas for his culture. ${ }^{60}$ Moreover, a celebration of the Theban leader in Plutarch's life dedicated to him may obviously be suspicious; and it must be remarked that the biographer praises Pelopidas' success at Susa omitting that it was at least partially due to the support of the

(57) BuCKLER 1982, p. 186; RIEDINGER 1991, p. 181; RoOd 2012, p. 92-94.

(58) Piccirilli 2002, p. 75.

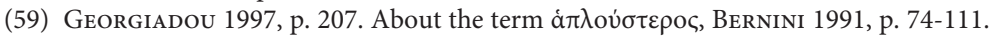

(60) See e.g. Plut. Pel. 4.1. However, they both came from aristocratic families (PASCUAL GonZÁLEs 2018, p. 92-93). 
Athenian ambassador Timagoras. ${ }^{61}$ Furthermore, according to Plut. Artax. 22.8, also Ismenias ${ }^{62}$ was part of this Theban embassy ${ }^{63}$ : if this information is reliable, it would be noteworthy that in a couple of occasions (Artax. 22.8 and Mor. 819c) Pelopidas did not serve as ambassador alone, but was accompanied by other Theban leaders. Delegations consisting in more than one envoy are not uncommon in the Greek world, ${ }^{64}$ but this could be interpreted also as a hint of the fact that Pelopidas was not the most skilful speaker of the Theban diplomacy. In conclusion, it seems to me that Pelopidas was not inadequate in speaking as ambassador in official occasions, but probably he was less skilled than others. Maybe he took part in the embassy to Susa with the purpose of suggesting arguments to the official speaker (Ismenias?), if not of speaking himself, since being unable to speak does is not exactly the same of being unable to find the right arguments to support a claim. In other words, it can't be excluded that Pelopidas was the mastermind of the Theban diplomatic speeches held in Susa, if not the actual speaker.

We have more information about Epaminondas, although it is preserved by not contemporary sources like Diodorus, Nepos and Plutarch, which provide details very similar to each other possibly because they share an Ephorean origin. ${ }^{65}$ Epaminondas is mentioned as Theban ambassador in the following occasions: the congress in Sparta before Leuctra (nr. 8); the assembly held in Arcadia in 366 (nr. 12); and the peace of 375 (nr. 7), the historical reliability of which is questioned (but this issue is not crucial in this paper, because Diodorus' passage is used here only as evidence of the existence of evaluations about Epaminondas' diplomatic oratory; it is less important here from which specific occasions these evaluations were generated) ${ }^{66}$

As for the content of Epaminondas' speeches, the analysis has been conducted above: the cases nr. 8 and 12 provide several rhetoric strategies such as analyses of the present situation and also the use of propagandistic slogans, of rhetorical and provocative questions and of sarcasm as well; the case nr. 7 does not supply any additional information, because it does not preserve an actual indirect speech of Epaminondas. Besides, it is worth noting that in two cases he was able to use an argument to which one of his opponents had appealed and to reverse it in his own favour: this aspect, known from different sources for different episodes, could indeed be an original trait of Epaminondas' diplomatic oratory and a peculiar skill of him. In addition, these two episodes belong to different historical periods, respectively before and after Leuctra, which shows that this kind of rhetoric strategy is used regardless of the political situation, whether Thebes was hegemon in Greece or not.

As for the evaluations of Epaminondas' oratory, all cases present interesting remarks.

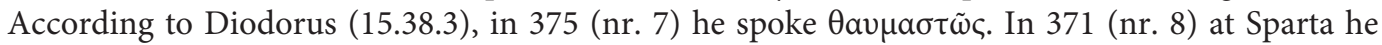

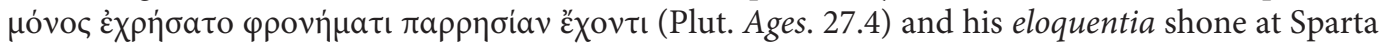
so much that non minus illa oratione opes eorum concusserit quam Leuctrica pugna (Nep. Epam. 6.4). Sources highlight that his ability to speak was extraordinary, that he spoke with frankness,

(61) For this remark, see Georgiadou 1997, p. 211 and Bearzot 2008-2009, p. 104 n. 24. For the role of Timagoras, see Xen. Hell. $7.1 .35 ; 38$.

(62) The son of the more popular Ismenias, sentenced to death by Leontiades (Xen. Hell. 5.2.36): see Bearzot 20082009, p. 100 n. 1; Schachter 2016b, p. 77-78; Pascual Gonzáles 2018, p. 93.

(63) See above, n. 47.

(64) See e.g. Mosley 1965, p. 255-266.

(65) No information about Epaminondas' diplomatic oratory is provided by Xenophon: in fact, Epaminondas' speech in Xen. Hell. 7.4.40 is not the speech of an ambassador, given that it was delivered in Thebes (for this speech, see BUCKLER 1982, p. 202). For Xenophon's Epaminondas, see WestlaKe 1975, p. 23-40.

(66) It can not be excluded that Diodorus confused this pace with that of 371 before Leuctra, also because some similarities in the sources concerning the two alleged peaces are undeniable; against this assumption, see above, n. 8 . 
pride and confidence ${ }^{67}$ and that his oratory was so strong and effective that he overcame the Spartans by his speech as much as he later did at Leuctra by his army. This picture is consistent with the information provided by sources about Epaminondas' culture (see e.g. Diod. 15.39.2-3) and eloquence, best known from Nepos (Epam. 5-6) and Plutarch (Mor. 192c-194c): notably, Nepos remarks that he was so disertus that there was no Theban like him in eloquentia, because he was both concinnus in brevitate respondendi and ornatus in perpetua oratione.$^{68} \mathrm{Clearly}$, when he was an ambassador, he used his culture and his rhetorical skills for delivering powerful speeches of which unfortunately only little evidence has been preserved. Besides, in at least one occasion it is known that Epaminondas was member of a wider embassy, but the sources mention only his words and not those of his colleagues, sign that his remarks were the most impressive and powerful. ${ }^{69}$

Although sources are not numerous, we tried to find some characteristics of Pelopidas and Epaminondas as ambassadors who delivered speeches. In addition to what noted above, a couple of concluding remarks can be provided. First, the names of almost all the Theban ambassadors are lost apart from those of Pelopidas and Epaminondas ${ }^{70}$ : this could depend on the fact that, as it is well known, Xenophon is surely not a supporter of the Thebans, but perhaps also on the fact that the sources considered worth mentioning only men who were well known for military or political reasons. ${ }^{71}$ Besides, concerning specifically diplomatic oratory, it could be significant that there is no occasion in which these two ambassadors are mentioned without either reminding that they delivered a speech during the embassies or reporting an indirect speech: in other words, the fact that a Theban ambassador is explicitly mentioned by name seems to imply that usually, given his political importance, it is also provided at least a mention of a speech delivered by him.

\section{CONCLUSION}

This survey provided interesting remarks both about rhetorical strategies commonly used by Theban ambassadors and about the oratory of Pelopidas and Epaminondas, even if the sources do not allow to detect substantial differences for Theban ambassadorial speeches compared to that of the rest of Greece. It is well known and it is suggested also by Aristotle's passage mentioned at the beginning of this paper that "Laconic speaking" is a peculiar feature of Spartan speeches, also in diplomatic field ${ }^{72}$ : nothing equally distinguishing can be identified in the forty years considered for Theban diplomatic oratory, in terms of style or argumentations used. If we compare arguments usually adopted in diplomatic oratory ${ }^{73}$ with those listed above, no substantial difference or peculiarity can be identified. In the present study the appeal to the syngeneia is lacking, but this does not seem to me very significant, because it could be due either to specific political contexts, or to the

(67) SHIPley 1997, p. 311.

(68) Regarding Epaminondas' culture and oratorical skills in Nepos, see: BradLEy 1991, p. 91-92; BonACCORso 2013, p. 21-49 (particularly, p. 30-31 and 42-44; see also p. 45-46 for Ephorus as Nepos' source).

(69) According to Xenophon (Hell. 6.3.19), the Thebans sent to the congress at Sparta in $371 \pi \rho \varepsilon \delta \beta \varepsilon เ \varsigma$ (plural), but the other sources mention only a speech by Epaminondas; it can not be excluded that also other ambassadors spoke in that occasion, but in any way the speech of Epaminondas was the only one considered worthy of mention. About this episode, see above, par. I.4.

(70) For a mention of Ismenias in Plut. Artax. 22.8, see above n. 47.

(71) I am not entirely convinced that in the fourth century in central Greece there was a separation between orator and general (PAscual GonzÁles 2018, p. 98): the cases of Pelopidas and Epaminondas seem to suggest otherwise.

(72) Regarding "Laconic speaking" see: Cozzo 1991, p. 1371-1378; BAYLISs 2009, p. 231-260; and specifically in diplomatic field PiCCIRILLI 2002, 110-113.

(73) Piccirilli 2002, p. $63 \mathrm{ff}$. 
selection operated by the sources ${ }^{74}$; and, besides, this topic recurs in the Theban speech at Plataia in $427 / 6$ (that furthermore has a wide section devoted to reconstruct past events), which proves that this kind of matter was not unknown to Theban diplomacy. ${ }^{75}$ It is however significant that, according to the speeches preserved by ancient sources, the Thebans, in the period in which they were increasing their power and then gained the hegemony, perfectly fit in the tradition of Greek diplomatic oratory and recurred to rhetorical strategies and types of arguments already in use.

The primary task of ambassadors was to persuade or dissuade their audience. ${ }^{76}$ In the present survey several methods emerged, that affect rational thinking (e.g. the references to the past) or the emotional side (e.g. the use of sarcasm or of rhetorical questions). Two techniques of persuasion seem to me particularly interesting.

In the first place, the appeal to remote or recent past, because it is the instrument most frequently used, clearly since it was effective: the ambassador, emphasizing some aspects and omitting others in his reconstruction of the past, or choosing certain examples and omitting others, could orientate and manipulate the audience in order to make it incline in favour of his own view; in fact, no blatant forgery appeared in the considered speeches, because otherwise it would be selfdefeating for the purposes of the ambassador, but rather only slight alterations inserted in order to present facts in a certain light. According to the considered sources, after Leuctra references to the past are particularly frequent, both to the ancient past (Second Persian War, nr. 11) and to facts belonging to the fourth century (Agesilaus' mission in Asia, nr. 11), but even to the most recent events (battle of Leuctra, nr. 9). Obviously, the frequency of these references to the past may be completely fortuitous, depending both on the sources we have and on the occasions in which this kind of argument is used (e.g., the historical references in speech nr. 11 aim at proving to Artaxerxes that the Thebans have always been loyal to the Persian empire). However, it seems significant that, at the time when the Thebans had to legitimate their own hegemony and their claims as leaders of the Greece, they recur to the appeal to the past.

In the second place, we have to remark the use of propagandistic slogans: matters such as the

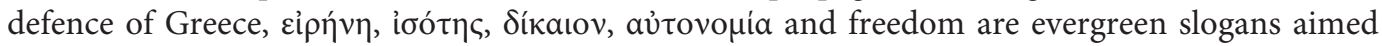
at obtaining the favour of the audience. It is significant that this oratorical strategy is used both before Leuctra (by Epaminondas) and during the Theban hegemony (by Pelopidas): on the eve of Leuctra, it is used because the Thebans, harshly criticising Spartan hegemony, were about to propose themselves at the head of Greece; while in the peace congress of Susa, because, presenting themselves as champions of the autonomy, they showed publicly to be the hegemons of the Greeks.

In addition, a special mention should be made for other rhetorical strategies: the argument of the merits achieved in the past, which is at the same time a "rational" and a "moral" argument; the claim of ambassadors that the reconstruction of the past events provided by them was actually true; and also the fact that in 395 the Thebans propose to the Athenians to recover their hegemony, which is a strong and highly persuasive argument used by a "third force" like Thebes.

(74) Concerning the use of syngeneia in diplomatic speeches PiCCIRILli 2002, p. 79-87 and BolmarCiCH 2010, p. 125133.

(75) Concerning the speech of 427/6: Thuc. 3.61.2; 65.3 for the use of syngeneia (see also Fragoulaki 2013, 122-123); and Thuc. 3.62-66 for the use of the past, both remote (Persian wars) and recent (Theban attack on Plataea).

(76) With regard to the importance of persuasion in ambassadors' speeches, see Piccirilli 2002, p. 73-75. The art of persuasion has been widely studied but usually not in its particular relation with diplomatic oratory: see e.g. KENNEDY 1963 (in p. 125-263 he deals with several rhetorical genres, such as the classic judicial, epideictic and deliberative, but no specific section is devoted to diplomatic oratory) and WORTHINGTON 1994 (with many papers about persuasion and its applications, but without references to the field of diplomacy). Concerning persuasion in Theban international relations, see also ORSI 2002, p. 103-104 (but with examples not related to diplomatic speeches). 
These (and the other) persuasion techniques show that the valid (Theban) ambassador must have been not only an eloquent speaker, but also a skilled historian and a clever politician. This picture fits exactly with Epaminondas, who was ambassador in two of the considered cases (nr. 8 and 12), the only named Theban who, along with Pelopidas, appears as a speaker in embassies. An eventual future broadening of the present enquiry could both consider a wider chronological period and investigate about other Theban political leaders who served as ambassadors.

Paolo A. TucI

Università cattolica del Sacro Cuore di Milano

\section{Bibliography}

Adcock, F., Mosley, D. J., 1975, Diplomacy in Ancient Greece, London.

Badian, E., 2004, "Xenophon the Athenian", in C. Tuplin (ed.), Xenophon and His World. Papers from a Conference Held in Liverpool in July 1999, Stuttgart, p. 33-53.

Baragwanath, E., 2012, “A Noble Alliance: Herodotus, Thucydides, and Xenophon's Procles”, in E. Foster, D. Lateiner (eds.), Thucydides and Herodotus, Oxford, p. 316-344.

Baragwanath, E., 2017, "The Character and Function of Speeches in Xenophon", in M. A. Flower (ed.), The Cambridge Companion to Xenophon, Cambridge, p. 279-297.

Bayliss, A. J., 2009, "Using Few Words Wisely? 'Laconic Swearing' and Spartan Duplicity", in S. Hodkinson, T.D. BARnes (eds.), Sparta: Comparative Approaches, Swansea, p. 231-260.

Bearzot, C., 2004, Federalismo e autonomia nelle Elleniche di Senofonte, Milano.

BeArzot, C., 2004-2005, “Ateniesi e Spartani reciproci salvatori: un topos tra retorica e storiografia", ACD 40-41 (Studi Havas), p. 17-32.

Bearzot, C., 2008-2009, "L'ambasceria ateniese a Susa (367 a.C.)", in Guerra e diplomazia nel mondo antico. Tra istanze politiche e strategie culturali, Giornate di studio, Palermo, 21-22 novembre 2008, Hormos Ricerche di Storia Antica, n.s., 1 (2008-2009), p. 100-110 (=Bearzot, C., 2012, "Xenophon on the Athenian Embassy to Susa (367 B.C.)", Historikà 1, p. 21-37).

Bearzot, C., 2011, "L'antica egemonia di Orcomeno in Beozia: fortuna di un tema propagandistico" in L. Breglia, A. Moleti, M. L. Napolitano (a cura di), Ethne, identità e tradizioni: la «terza» Grecia e l'Occidente, 1, Pisa, p. 271-284.

Bearzot, C., in press, "Pseudos e aletheia in Senofonte", in B. Battistin Sebastiani, O. Deviller (éd.), Sources et modèles des historiens anciens, II.

Bernini, U., 1991, "Haplous ehaplotes: in margine a Plut., Pelopidas, 30-31", Studi italiani di filologia classica 9, p. 74-111.

Binder, C., 2008, Plutarchs Vita des Artaxerxes. Ein historischer Kommentar, Berlin-New York.

Bolmarcich, S., 2010, "Communal Values in Ancient Diplomacy", in R. M. Rosen, I. Stuiter, Valuing Others in Classical Antiquity, Leiden-Boston, p. 113-135.

Bonaccorso, G., 2013, "Cornelio Nepote e le virtù di Epaminonda”, in G. Solaro (a cura di), La Roma di Cornelio Nepote, Roma, p. 21-49.

Bradley, J. R., 1991, The Sources of Cornelius Nepos. Selected Lives, New York-London.

BuCK, R. J., 1994, Boiotia and the Boiotian League, 432-371 B.C., Edmonton.

BuCKLeR, J., 1980, The Theban Hegemony 371-362 B.C., Cambridge-London.

Buckler, J., 1982, "Xenophon's Speeches and the Theban Hegemony", Athenaeum 60, p. 180-204 (= in J. Buckler and H. Beck (eds.), Central Greece and the Politics of Power in the Fourth Century B.C., Cambridge 2008, p. 140-164). 
Buckler, J., 2000, “A Survey of Theban and Athenian Relations between 403 and 371 B.C.”, in P. Angeli Bernardini (a cura di), Presenza e funzioone della città di Tebe nella cultura greca. Atti del Convegno Internazionale (Urbino, 7-9 luglio 1997), Pisa-Roma, p. 319-329. (= in J. Buckler, H. Beck (eds.), Central Greece and the Politics of Power in the Fourth Century B.C., Cambridge 2008, p. 33-43).

Canevaro, M., 2017, “La memoria, gli oratori e il pubblico nell'Atene del IV secolo a.C.”, in E. FranCHI, G. Proietti (a cura di), Conflict in Communities. Forward-looking Memories in Classical Athens, Trento, p. 171-212.

Cozzo, A., 1991, "Note sulla condotta linguistica degli Spartani", in Studi di Filologia classica in onore di Giusto Monaco, IV, Palermo, p. 1371-1378.

DAlfen, J., 1976, "Xenophon als Analytiker und Kritiker politischer Rede (Zu Hell. VI 3, 4-17 und VI 5, 33-48)", Grazer Beiträge 5, p. 53-84.

Dillery, J., 1995, Xenophon and the History of His Times, London-New York.

Dorjahn, A.P., Fairchild, W.D., 1975, “On Xenophon, Hellenica 2.3.24-49”, The Classical Bulletin 51, p. 60-62.

Ferrario, S.B., 2012, "Historical Agency and Self-Awareness in Xenophon's Hellenica and Anabasis", in F. Hobden and C. Tuplin (eds.), Xenophon: Ethical Principles and Historical Enquiry, Leiden, Boston (Mnemosyne Suppl. 348), p. 341-376.

Fossey, J. M. (ed.), 1991, Epigraphica Boeotica, I, Studies in Boiotian Inscriptions, Amsterdam.

Fossey, J. M. (ed.), 2014, Epigraphica Boeotica, II, Further Studies in Boiotian Inscriptions, Leiden-Boston.

Fragoulaki, M., 2013, Kinship in Thucydides: Intercommunal Ties and Historical Narrative, Oxford.

Gartland, S. D., 2016a, Boiotia in the Fourth Century B.C., Philadelphia.

Gartland, S.D., 2016b, "Enchanting History: Pausanias in Fourth-Century Boiotia”, in S.D. Gartland (ed.), Boiotia in the Fourth Century B.C., Philadelphia, p. 80-98.

Georgiadou, A., 1997, Plutarch's Pelopidas. A Historical and Philological Commentary, Stuttgart.

Gray, V.J., 1981, "Dialogue in Xenophon's Hellenica”, CQ 31, p. 321-334.

Gray, V.J., 1987, “The Herodotean nature of speeches in the Hellenica”, Abstracts of the American Philological Association 58, p. 75.

Gray, V.J., 1989, The Character of Xenophon's Hellenica, Baltimore.

Higgins, W.E., 1977, Xenophon the Athenian: the Problem of the Individual and the Society of the 'Polis', Albany.

Jehne M., 1994, Koine Eirene. Untersuchungen zu den Befriedungs- und Stabilisierungsbemühungen in der griechische Poliswelt des 4. Jahrhunderts v. Chr., Stuttgart (Hermes Einzel. 63).

Kennedy, G. A., 1963, The Art of Persuasion in Greece, Princeton.

KrentZ, P. M., 1995, Hellenika II.3.11-IV.2.8, Warminster.

Low, P., 2007, Interstate Relations in Classical Greece: Morality and Power, New York.

Mackil, E., 2013, Creating a Common Polity. Religion, Economy, and Politics in the Making of the Greek Koinon, Berkeley-Los Angeles-London.

Mackil, E., 2014, "Creating a Common Polity in Boeotia", in N. Papazarkadas (ed.), The Epigraphy and History of Boeotia: New Finds, New Prospects, Leiden-Boston, p. 45-67.

Magnetto, A., 2013, “Ambasciatori plenipotenziari delle città greche in età classica ed ellenistica: terminologia e prerogative", in M. MARI, J. Thornton (a cura di), Linguaggio politico e lessico storiografico in età ellenistica, Pisa-Roma, p. 223-241.

Magnetto, A., 2019, "I rapporti tra i diversi soggetti politici: la diplomazia internazionale”, in M. MARI (a cura di), L'età ellenistica. Società, politica, cultura, Roma, p. 81-106.

Marincola, J. M., 2007, “Speeches in Classical Historiography”, in J. M. Marincola (ed.), A Companion to Greek and Roman Historiography, Malden (MA) - Oxford, p. 118-132. 
Marincola, J.M., 2010, “The Rhetoric of History: Allusion, Intertextuality, and Exemplarity in Historiographical Speeches”, in D. PAusch (hrsg.), Stimmen der Geschichte: Funktionen von Reden in der antiken Historiographie, Berlin - New York, p. 259-289.

Moggi, M., 2010, in Pausania, Guida della Grecia. Libro IX. La Beozia, Milano.

Mosley, D. J., 1965, “The Size of Embassies in Ancient Greek Diplomacy”, TAPhA 96, p. 255-266.

MosLey, D. J., 1972, “The Theban Diplomacy in 371”, REG 85, p. 312-318.

Mosley, D. J., 1973, Envoys and Diplomacy in Ancient Greece, Wiesbaden (Historia Einzel. 22).

Occhipinti, E., 2016, The Hellenica Oxyrhynchia and Historiography. New Research Perspectives, Leiden.

Orsi, D.P., 2002, "Trattative internazionali nelle Elleniche senofontee. Aspetti del lessico: i verbi della comunicazione”, in L. PICCIRILli (a cura di), La retorica della diplomazia nella Grecia antica e a Bisanzio, Roma, p. 69-109.

Papazarkadas, N. (ed.), 2014, The Epigraphy and History of Boeotia: New Finds, New Prospects, Leiden, Boston.

Pascual Gonzáles, J., 2018, "Commanders and Warlords in Fourth Century B.C. Central Greece", T. Ňaco Del Hoyo, F. López SÁncez (eds.), War, Warlords, and Interstate Relations in the Ancient Mediterranean, Leiden-Boston, p. 89-112.

PePe, C., 2013, The Genres of Rhetorical Speeches in Greek and Roman Antiquity, Leiden, Boston.

Perlman, S., 1964, “The Causes and the Outbreak of the Corinthian War”, CQ 58, p. 64-81.

Piccirilli, L., 2002, L'invenzione della diplomazia nella Grecia antica, Roma.

Pontier, P., 2013, "L'utilisation de l'histoire dans les discours politiques de Xénophon de Marathon à Platées", Dialogues d'histoire ancienne Suppl. 8, p. 165-187.

Pownall, F., 2004, Lessons from the Past: The Moral Use of History in Fourth-Century Prose, Ann Arbor.

Riedinger, J.-C., 1991, Étude sur les Helléniques. Xénophon et l'histoire, Paris.

Rood, T., 2004, "Panhellenism and Self-Presentation: Xenophon's Speeches”, in R. Lane Fox (ed.), The Long March: Xenophon and the Ten Thousand, New Haven-London.

Rood, T., 2012, “The Plupast in Xenophon's Hellenica”, in J. Grethlein, C.B. Krebs (eds.), Time and Narrative in Ancient Historiography. The 'Plupast' from Herodotus to Appian, Cambridge, p. 76-94.

Rubinstein, L., 2016, "Envoys and Ethos: Team Speaking by Envoys in Classical Greece”, in E. EdwARds (ed.), La rhétorique du pouvoir. Une exploration de l'art oratoire délibératifgrec, Vandoeuvres, p. 79-128.

RzepKA, J., 2010, "Plutarch on the Theban Uprising of 379B.C. and the boiotarchoi of the Boeotian Confederacy under the Principate", Historia 59, p. 115-118.

Schachter, A., 2014, Tlepolemos in Boeotia, in N. Papazarkadas (ed.), The Epigraphy and History of Boeotia: New Finds, New Prospects, Leiden-Boston, p. 313-331.

Schachter, A., 2016a, Boiotia in Antiquity. Selected Papers, Cambridge.

Schachter, A., 2016b, "Politics and Personalities in Classical Thebes", in A. Schachter (ed.), Boiotia in Antiquity. Selected Papers, Cambridge, p. 66-79 (= in R. B. EgAn, M. Joy AL (eds)., Daimonopylai: Studies Presented to Edmund G. Berry, Winnipeg 2004, p. 347-361).

Schepens, G., 2001, “Three Voices on the History”, in A. Barzanò, C. Bearzot, F. Landucci, L. Prandi, G. ZECCHINI (a cura di), Identità e valori. Fattori di aggregazione e fattori di crisi nell'esperienza politica antica, Bergamo, 16-18 dicembre 1998, Roma, p. 81-96.

Schepens, G., 2012, “Timocrates’ Mission to Greece. Once Again”, in F. Hobden, C. Tuplin (eds.), Xenophon: Ethical Principles and Historical Enquiry, Leiden, Boston (Mnemosyne Suppl. 348), p. 228-231.

Shipley, D. R., 1997, A Commentary on Plutarch's Life of Agesilaos, Oxford.

Sordi, M., 1950, "I caratteri dell'opera storiografica di Senofonte nelle Elleniche", Athenaeum 28, p. 3-53.

Sordi, M., 1951, “I caratteri dell'opera storiografica di Senofonte nelle Elleniche. Parte seconda”, Athenaeum 29, p. 273-348.

Sordi, M., 1966, "Mitologia e propaganda nella Beozia arcaica”, Atene e Roma 11, p. 15-24 (= in M. SordI, Scritti di storia greca, Milano 2002, p. 271-283). 
Sordi, M., 1974, "Propaganda politica e senso religioso nell'azione di Epaminonda", in M. SoRdi (a cura di), Propaganda e persuasione occulta nell'antichità, Milano (CISA 2), p. 45-53.

Sordi, M., 1995, "Tendenze storiografiche e realtà storica nella liberazione della Cadmea in Plut., Pel. 5-13", in Teoria e prassi politica nelle opere di Plutarco. Atti del V convegno plutarcheo (e III congresso internazionale della International Plutarch Society), Certosa di Pontignano, 7-9 giugno 1993, Napoli, p. 415-422.

Soulis E. M., 1972, Xenophon and Thucydides, Athens.

Sterling, N., 2004, "Xenophon's Hellenica and the Theban Hegemony", in C. Tuplin (ed.), Xenophon and His World. Papers from a Conference Held in Liverpool in July 1999, Stuttgart, p. 453-462.

Stylianou P.J., 1998, A Historical Commentary on Diodorus Siculus. Book 15, Oxford.

Tamiolaki, M., 2014, “À l’ombre de Thucydide? Les discours des Helléniques et l'influence thucydidéenne", in P. Pontier (éd.), Xénophon et la rhétorique, Paris, p. 121-138.

Tuplin, C., 1993, The Failings of Empire. A Reading of Xenophon Hellenica 2.3.11-7.5.27, Stuttgart (Historia Einz. 76).

Usher, S., 1968, "Xenophon, Critias and Theramenes", JHS 88, p. 128-135.

Vela TejadA, J., 2005, "Historiografía y biografía: a propósito de la reconquista de la Cadmea tebana (Plutarco, Pelópidas 7-13)", in A. Pérez Jiménez, F. Bonner Titchener (eds.), Historical and Biographical Values of Plutarch's Works: Studies Devoted to Professor Philip A. Stadter by the International Plutarch Society, Logan, p. 465-477.

Westlake, H.D., 1975, "Xenophon and Epaminondas", GRBS 16, p. 23-40.

Westlake, H.D., 2010, "The Sources for the Spartan Debacle at Haliartus", in V.J. Gray (ed.), Oxford Readings in Classical Studies. Xenophon, Oxford, 457-475.

Winter, J., 2016, “(Re)interpreting Xenophon's Speeches: Euphron's Killer to the Theban Council (Hellenica 7.3.7-11)", Auctor Journal 1, p. 2-14.

Wooten, C.W., 1973, “The Ambassador'sSpeech:a ParticularlyHellenistic Genre of Oratory”, QJS59, p. 209-212.

Worthington, I., (ed.), 1994, Persuasion: Greek Rhetoric in Action, London. 